\title{
KEPEMIMPINAN DAN LOYALITAS TERHADAP KINERJA KARYAWAN RSJ MENUR SURABAYA
}

\author{
A. Suyunus Adiwibowo \\ Rumah Sakit Asrama Haji Surabaya \\ E-mail: as_adiwibowo@yahoo.co.id
}

\begin{abstract}
This study's purpose were: 1) To know and analyze whether the commitment, loyalty and discipline of work simultaneously influence to the ability of employees at Menur regional mental hospital, Surabaya. 2) To know and analyze if commitment, loyalty and discipline of work can partially affect the ability of employees, 3) To know and analyze which among commitment, loyalty and discipline of work have the most dominant influence on the ability of employees at Menur regional mental hospital. Data was collected from employees at the regional mental hospital by using questionnaires. Analyses method uses multiple linear regression analysis, correlation coefficient, coefficient of determination, simultaneous tests and partial tests. The result of this study indicate that commitment, loyalty and discipline of work have significant influences on the ability of the regional mental hospital employees simultaneously and partially, while the most dominant influence is work discipline.
\end{abstract}

Keywords: commitment, loyalty, discipline and ability to work of employees.

\section{PENDAHULUAN}

Berdasarkan Program Pokok Kesehatan dengan Visi Indonesia sehat 2010 salah satu Misinya adalah" Memelihara dan meningkatkan pelayanan kesehatan yang bermutu, merata dan terjangkau." Adapun salah satu strateginya adalah profesionalisme pada tenaga kesehatan. Tenaga kesehatan adalah setiap orang yang mengabdikan diri dalam bidang kesehatan serta memiliki pengetahuan dan atau ketrampilan melalui pendidikan di bidang kesehatan yang untuk jenis tertentu memerlukan kewenangan untuk melakukan upaya kesehatan. Dengan profesionalisme tenaga kesehatan diharapkan nantinya mampu memberikan landasan yang kuat bagi kualitas sumber daya manusia sehingga mampu berkompetisi di era global.

Rumah sakit adalah sebuah institusi perawatan kesehatan profesional yang pelayanannya disediankan oleh dokter, perawat, bidan dan tenaga ahli kesehatan lainnya. Tenaga kesehatan/ sumber daya manusia (SDM) merupakan aset suatu organisasi rumah sakit. Masa depan dan kelestarian suatu organisasi rumah sakit tergantung pada pengetahuan, ketrampilan dan kompetensi tenaga kesehatan, serta sinergi antara SDM sebagai penggerak organisasi dan pengelolaan yang efektif sumber daya lainnya yang ada dalam organisasi tersebut. SDM merupakan aset yang paling komplek untuk dikelola karena keunikan individu, perbedaan kompetensi, kualifikasi, keahlian serta latar belakang SDM yang menjadi bagian dari suatu organisasi.

Pengelolaan SDM yang efektif untuk menghasilkan produktifitas organisasi perlu pendekatan manajerial yang holistik. Salah satu pendekatan yang penting dalam menggelola SDM adalah penggunaan kepemimpinan yang efektif dengan penggunaan gaya yang sesuai dengan tingkat maturitas karyawan.

Rumah Sakit Jiwa Daerah Menur Surabaya adalah rumah sakit kelas Akhusus milik Pemerintah Propinsi Jawa Timur yang merupakan sebuah institusi pelayanan kesehatan jiwa yang mempunyai Visi " menjadi pusat rujukan pelayanan kesehatan jiwa yang profesional dengan pelayanan prima yang mengutamakan kepuasan pelanggan di Propinsi 
Jawa Timur tahun 2010". Adapun Jumlah karyawan seluruhnya ada 376 , dengan perician tenaga kesehatan sebanyak 144 orang dan tenaga non kesehatan sebanyak 232 orang.( profil Rumah Sakit Jiwa Daerah Menur Surabaya, 2009)

Dengan semakin kritisnya masyarakat, maka pelayanan kesehatan di Rumah Sakit Jiwa Daearah Menur Surabaya perlu ditingkatkan agar mampu bersaing dengan rumah sakit swasta/ pemerintah lainnya. Mereka akan terus dituntut untuk meningkatkan pelayanannya baik secara kuantitas maupun kualitasnya.

Karena adanya tantangan baru untuk meningkatkan pelayanan publik baik kualitas maupun kuantitasnya, maka Pengelola Rumah Sakit Jiwa Daerah Menur Surabaya harus segera melakukan peningkatan dan pengembangan kemampuan, pengetahuan serta ketrampilan karyawannya. Salah satu usaha yang bisa dilakukan untuk mengetahui adanya perbedaan tingkat kemampuan, ketrampilan dan pengetahuan karyawan, serta untuk memperoleh karyawan yang memiliki tingkat kompetitif yang tinggi, ialah dengan melakukan penilaian atas semua perilaku dan kegiatannya dalam melaksanakan tugas dan kewajibannya sehari-hari. Harapan dari peningkatan dan pengembangan kompeten karyawan ini adalah tercapainya kinerja atau produktifitas individu yang akhirnya menentukan produktifitas organisasi dengan ditandai efektifitasnya organisasi.

Produktifitas organisasi dibangun oleh kinerja seluruh karyawan, dan kinerja organisasi tersebut dapat dinilai beberapa orang antara lain oleh para atasan langsung, pegawai menilai atasannya, anggota kelompok yang menilai satu sama lain (rekan sejawat), sumber-sumber dari luar misalnya pelanggan (pasien dan keluarganya), penilaian karyawan sendiri dan penggunaan penilai dari berbagai sumber atau yang saat ini dikenal dengan istilah metode penilaian dengan multi sumber atau penilaian 360 derajat/ 360-degree appraisals. (Mathis, 2000).

Gibson (1996) menyatakan bahwa kinerja individu dipengaruhi oleh tiga faktor yaitu faktor individu itu sendiri, faktor psikologis dan faktor organisasi. Gibson menambahkan bahwa apapun bentuk, sifat dan ukuran organisasi, keberhasilan organisasi pada dasarnya merupakan akumulasi dari agregat usaha sekaligus keberhasilan individu, oleh karena itu peran karyawan dalam rangka meningkatkan kinerja organisasi merupakan faktor yang paling dominan. Sedangkan faktor yang menentukan tingkat kinerja individu ditentukan sejauh mana maturitas karyawan dalam melaksanakan pekerjaan.

Kinerja karyawan dalam penelitian ini adalah prestasi yang dicapai oleh karyawan Rumah Sakit Jiwa Daerah Menur Surabaya dalam melaksanakan tugasnya atau kerjaannya sesuai dengan standar dan kriteria perilaku kerja yang ditetapkan. kinerja karyawan dipengaruhi oleh beberapa faktor, kemungkinan diantaranya faktor individu (kemampuan, ketrampilan, biografis, persepsi, sikap, kepribadian, pembelajaran, motivasi dan maturitas), faktor organisasi (struktur, teknologi, dan iklim kerja) dan faktor manajerial (komunikasi, kepemimpinan, pengambilan keputusan, dan pemberian motivasi (Ilyas, 2002; Robbins, 2003 dan Monica, 1998).

Menurut Hersey-Blanchard (1982) konsep kematangan/maturity terdiri dari dua dimensi maturitas pekerjaan yang berkaitan dengan kemampuan/ability untuk melakukan sesuatu dan maturitas psikologis yang dikaitkan dengan kemauan/willingness untuk melakukan sesuatu atau memikul tanggung jawab dalam mengarahkan perilaku mereka sendiri. Kajian kemampuan dan gaya kepemimpinan ini menggunakan pendekatan kajian teori The Situational Leadership Theory (SLT) Hersey dan Blanchard (1982). Teori ini digambarkan sebagai salah satu untuk mendiagnosa tingkat kematangan suatu individu ataupun tingkat kematangan sistem dalam kemampuannya untuk menyelesaikan suatu masalah. Pada tingkat kematangan ini akan ditinjau terlebih dahulu job maturity karyawan yang dikaitkan dengan kemampuan/ ability dan psychology maturity dikaitkan dengan kemauan/ willingness. Sedangkan gaya kepemimpinan dikaji berdasarkan pada dua orientasi yaitu tugas dan hubungan.

Definisi kepemimpinan menurut Gary Yukl (2005) adalah kemampuan individu untuk mem- 
pengaruhi, memotivasi, dan membuat orang lain mampu memberikan kontribusinya demi efektivitas dan keberhasilan organisasi. Kepemimpinan merupakan suatu proses untuk membuat orang memahami manfaat bekerja bersama orang lain, sehingga mereka paham dan mau melakukannya. Konsepkonsep tersebut secara tegas menyatakan kedudukan pemimpin menentukan aktivitas menyelesaikan tugas atau pekerjaan dan karyawan yang menjadi area tanggung jawabnya, dengan demikian kepemimpinan sangat menentukan kinerja setiap karyawan. Sebagaimana dalam teori Situational Leadership Theory (SLT) Hersey, Blanchard (1982), menunjukkan hubungan antara kemampuan yang berkaitan dengan perilaku hubungan dan perilaku tugas bawahan dengan gaya kepemimpinan yang sesuai untuk diterapkan. Langkah awal seorang pemimpin akan mempengaruhi bawahannya maka terlebih dahulu mendiagnosis tingkat kemampuan bawahannya. Berdasar teori tersebut penelitian ini akan mengidentifikasi gaya yang sesuai bagi pemimpin sesuai dengan level kemampuan serta loyalitas karyawan.

Loyalitas dari kata loyal yang berarti setia. Loyal merupakan hubungan yang membuat seseorang percaya kepada orang lain. Loyalitas dibagi kedalam dua dimensi, yaitu: loyalitas sebagi perilaku/ behavior dan loyalitas sebagai sikap/ attitude. Kombinasi keduanya menghasilkan empat keadaan kemungkinan loyalitas, yaitu:1) Loyalitas rendah (sikap rendah, perilaku rendah), 2) Loyalitas laten (sikap tinggi, perilaku tinggi), 3) Loyalitas superioe (sikap rendah, perilaku tinggi), 4) Loyalitas sesungguhnya (sikap tinggi, perilaku tinggi). Lebih lanjut dimensi sikap dan perilaku memiliki lima indikator, yaitu:1). Trust (kepercayaan), 2). Psycological/ emotional commitment (komitmen psikologi/ emosi), 3). Switching cost (beban/ biaya yang harus ditangung bila pindah organisai), 4). Word of mouth (perilaku mempublikasikan organisasi), 5). Cooperation (perilaku kerjasama).

Berdasarkan hasil kajian faktor yang memungkinkan mempengarui kinerja karyawan, penelitian ini dibatasi kajian pada faktor individu yaitu kemampuan karyawaan dan loyalitas karyawan serta faktor managerial yaitu gaya kepe- mimpinan terhadap kinerja karyawan Rumah Sakit Jiwa Daerah Menur Surabaya. Hal ini dipertimbangkan bahwa di dalam upaya penyelenggaraan pelayanan kesehatan sangat ditentukan oleh SDM yang tersedia, sebagai modal dasar. Untuk menggerakkan organisasi dan mengembangkan kearah kemajuan dibutuhkan SDM yang handal yaitu yang memiliki tingkat kemampuan serta loyalitas yang tinggi. Fokus pada penggerak utama organisasi yaitu pemimpin organisasi, yaitu bagaimana pemimpin menjalankan gayanya di dalam mempengaruhi bawahannya sehingga mampu menuju pada tingkat kinerja yang tinggi.

Dalam penelitian ini penilaian kinerja menggunakan penilain oleh karyawan sendiri, sedangkan metode penilaian kinerja dengan metode penilaian dengan Behavior Observation Scale (BOS). BOS digunakan untuk mengidentifikasi perilaku karyawan yang akan dinilai, sedangkan cut of point untuk mengkategonikan tingkat kinerja karyawan adalah mean nilai kinerja. Penelitian ini dilaksanakan di Rumah Sakit Jiwa Daerah Menur Surabaya. Pemilihan ini dipertimbangkan dengan alasan bahwa rumah sakit tersebut merupakan salah satu rumah sakit pemerintah yang mempunyai jumlah karyawan banyak yaitu 376 karyawan,sedangkan jumlah tenaga kesehatan sebanyak 144 karyawan dan tenaga non kesehatan 232 karyawan sehingga dikuatirkan terjadi kecemburuan sosial antara sesama karyawan dalam pembagian jasa pelayanan.

\section{TINJAUANPUSTAKA}

Rivai (2005) mendifinisikan kinerja sebagai hasil atau tingkat keberhasilan orang secara keseluruhan selama periode tertentu di dalam melaksanakan tugas dibandingkan dengan berbagai kemungkinan, seperti standar hasil kerja, target atau sasaran atau kriteria yang telah ditentukan terlebih dahulu dan telah disepakati bersama. Pada hakikatnya kinerja merupakan prestasi yang dicapai oleh seseorang dalam melaksanakan tugasnya atau pekerjaannya sesuai dengan standar dan kriteria yang ditetapkan untuk pekerjaan itu. 
Dari pandangan tersebut kinerja mempunyai empat aspek, yaitu: (1) kemampuan; (2) penerimaan tujuan perusahaan; (3) tingkatan tujuan yang dicapai; dan (4) interaksi antara tujuan dan kemampuan para karyawan dalam perusahaan, di mana masing-masing elemen tersebut berpengaruh terhadap kinerja seseorang. Seorang karyawan tidak akan mampu bekerja dengan baik jika tidak memiliki kemampuan untuk mengerjakan pekerjaan tersebut. Meskipun pekerjaan itu dapat selesai dikerjakan, namun tidak membuahkan hasil yang memuaskan. Oleh karena itu, dalam rangka peningkatan kinerja seorang karyawan, pengetahuan bidang tugas pekerja yang bersangkutan sangat penting. Dengan demikian, faktor-faktor yang menandai kinerja adalah hasil ketentuan: (1) kebutuhan yang dibuat pekerja; (2) tujuan yang khusus; (3) kemampuan; (4) kompleksitas; (5) komitmen; (6) umpan balik; (7) situasi; (8) pembatasan; (9) perhatian pada setiap kegiatan; (10) usaha; (11) ketekunan; (12) ketaatan; (13) kesediaan untuk berkorban; dan (14) memiliki standar yang jelas.

Ilyas (2002) menyebutkan bahwa untuk mengetahui faktor yang mempengaruhi (determinan) kinerja personel, dilakukanlah pengkajian terhadap beberapa teori kinerja. Secara teoritis ada tiga kelompok variabel yang mempengaruhi perilaku kerja dan kinerja yaitu: variabel individu, variabel organisasi dan variabel psikologis. Ketiga kelompok variabel tersebut mempengaruhi perilaku kerja yang pada akhirnya berpengaruh pada kinerja personel. Perilaku yang berhubungan dengan kinerja adalah yang bekaitan dengan tugas-tugas pekerjaan yang harus diselesaikan untuk mencapai sasaran suatu jabatan atau tugas.

Gibson (1996) menyampaikan model teori kinerja dan melakukan analisis terhadap sejumlah variabel yang mempengaruhi perilaku dan kinerja individu. Variabel ini dikelompokkan pada subvariabel kemampuan dan ketrampilan, latar belakang dan demografis. Sub-variabel kemampuan dan ketrampilan merupakan faktor utama yang mempengaruhi perilaku dan kinerja individu. Variabel demografi mempunyai efek tidak langsung pada perilaku dan kinerja individu. Variabel psikologik terdiri dari sub-variabel per- sepsi, sikap, kepribadian, belajar, dan motivasi. Variabel psikologis ini sulit diukur dan banyak dipengaruhi oleh keluarga, tingkat sosial pengalaman kerja sebelumnya dan variabel demografis. Sedangkan faktor organisasi berefek tidak langsung terhadap sikap perilaku dan kinerja individu. Sub-variabel organisasi digolongkan dalam subvariabel sumber daya, kepemimpinan, imbalan, struktur, dan desain pekerjaan.

Menurut model partner-lawyer (Ivancevich, et al, 1994 dalam Rivai, 2005), kinerja individu dipengaruhi oleh faktor-faktor:(1) harapan mengenai imbalan;(2) dorongan;(3) kemampuan; kebutuhan dan sifat;(4) persepsi terhadap tugas;(5) imbalan internal dan eksternal;(6) persepsi terhadap tingkat imbalan dan kepuasan kerja. Dengan demikian, kinerja pada dasarnya ditentukan oleh tiga hal, itu:(1) kemampuan, (2) keinginan dan (3) lingkungan. Agar mempunyai kinerja yang baik, seseorang harus mempunyai keinginan tinggi untuk mengerjakan serta mengetahui pekerjaannya. Tanpa mengetahui ketiga faktor ini kinerja yang baik tidak akan tercapai. Dengan demikian, kinerja individu dapat ditingkatkan apabila ada kesesuaian antara pekerjaan, kemampuan, dan harapan.

Kinerja individu dipengaruhi oleh kepuasan kerja. Kepuasan kerja itu sendiri adalah perasaan individu terhadap pekerjaannya. Perasaan ini berupa suatu hasil penilaian mengenai seberapa jauh pekerjaannya secara keseluruhan mampu memuaskan kebutuhannya. Kepuasan tersebut berhubungan dengan faktor-faktor individu, yakni: (1) kepribadian seperti aktualisasi diri, kemampuan menghadapi tantangan, kemampuan menghadapi tekanan, (2) status dan senioritas, makin tinggi hierarkis di dalam perusahaan lebih mudah individu tersebut untuk puas, (3) kecocokan dengan minat, semakin cocok minat individu semakin tmggi kepuasan kerjanya; (4) kepuasan individu dalam hidupnya, yaitu individu yang mempunyai kepuasan yang tinggi terhadap elemen-elemen kehidupannya yang tidak berhubungan dengan kerja, biasanya akan mempunyai kepuasan kerja yang tinggi.

Faktor yang mempengaruhi kinerja adalah: karakteristik individu, karakteristik organisasi dan karakteristik pekerjaan, lebih lanjut beliau menje- 
laskan bahwa kinerja selain dipengaruhi oleh faktor di atas juga dipengaruhi oleh faktor lingkungan. Faktor yang mempengaruhi kinerja menurut Kopel- men seperti yang tercantum pada gambar 1 di bawah ini:

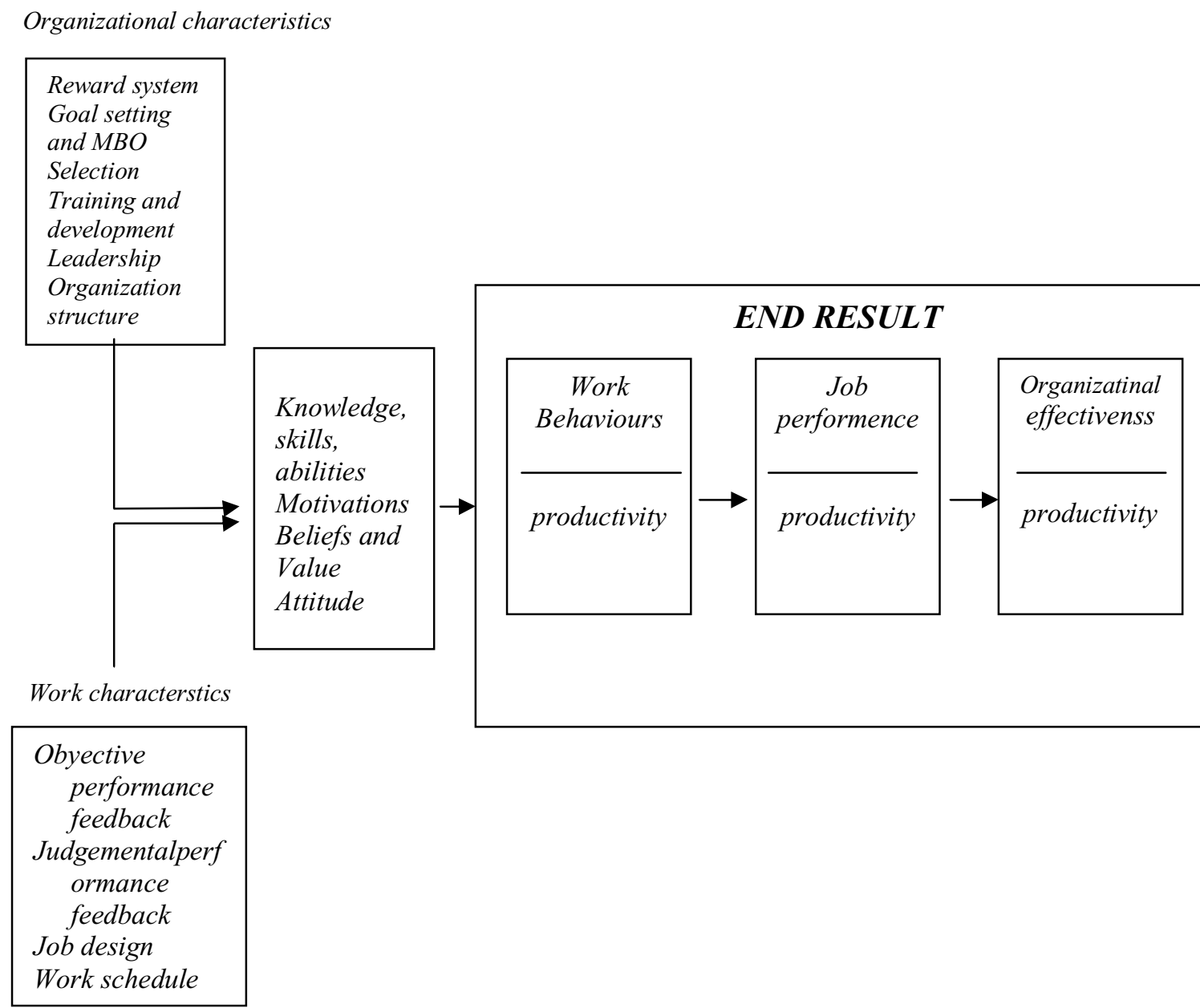

Gambar 1. Conceptual framework of the determinants of productivity in Organization-a behaviors Science approach (Kopelmen, 1998) Environment

Faktor individu dipengaruhi oleh tiga faktor yaitu pertama, faktor individu (kemampuan, ketrampilan, biografis, persepsi, sikap, kepribadian, pembelajaran, motivasi dan maturitas), kedua faktor organisasi (struktur, teknologi dan iklim kerja) dan ketiga faktor manajerial (komunikasi, kepemimpinan, pengambilan keputusan, dan pemberian motivasi) menurut Ilyas (2002), Robbins (2003) dan Monica (1998).

Penilaian kinerja/ performance appraisal dikenal juga dengan istilah evaluasi kinerja/ performance evaluation, performance rating, performance assessment, employee evaluation, merit rating, efficiency rating, service rating, yang pada dasarnya merupakan proses yang digunakan organisasi untuk mengevaluasi job performance (Rivai, 2005). Penilaian kinerja/ performanceappraisal adalah proses yang digunakan oleh organisasi untuk mengevaluasi pelaksanaan kerja individu karyawan. Penilaian kinerja ini dinilai kontribusi karyawan kepada organisasi selama periode waktu tertentu. Umpan balik/ performance feedback memungkinkan karyawan mengetahui seberapa baik mereka bekerja dibandingkan dengan standar. 
Dalam organisasi modern, penilaian kinerja merupakan mekanisme penting bagi manajemen untuk digunakan dalam menjelaskan tujuan dan standar kinerja dan memotivasi individu pada waktu berikutnya. Penilaian kinerja menjadi basis bagi keputusan yang menentukan telaah gaji, kesempatan promosi, pemberhentian, pelatihan dan pengembangan, serta program karir. Semua organisasi dapat mengevaluasi atau menilai kinerja dengan beberapa cara. Pada organisasi yang kecil, evaluasi ini mungkin sifatnya informal. Di dalam organisasi yang besar, atau penilaian kinerja sangat mungkin merupakan prosedur yang sistematik di mana sesungguhnya dari semua karyawan, manajerial, profesional, teknis, penjualan, dan akademika secara formal.

Aktivitas penilaian kinerja dilakukan oleh departemen sumber daya manusia, bisa berupa bagian kepegawaian, personalia, Manajemen Sumber Daya Manusia (MSDM)/ Human Resource Development (HRD). Proses penilaian ini dilakukan sesuai dengan besar kecilnya suatu organisasi, bila organisasi besar dilakukan dengan cara yang sifatnya formal yang dilakukan secara periodik waktu tertentu dan biasanya dilakukan setiap 1 atau 2 kali setahun, sedangkan informal dilakukan sesuai dengan kebutuhan manajer akan komunikasi atau informasi. Namun banyak organisasi memadukan penilaian kinerja formal dan informal tersebut. Penilai kinerja pegawai dilakukan beberapa orang antara lain oleh para atasan langsung, pegawai menilai atasannya, anggota kelompok yang menilai satu sama lain (teman sejawat), sumber-sumber dari luar, penilaian pegawai sendiri dan yang menggunakan kombinasi dari seluruh metode yang ada saat ini yaitu metode penilaian dengan multi sumber atau penilaian 360 derajat/ 360-degree appraisal (Mathis, 2001).

Suatu bagan elemen-elemen pokok dan sistem penilaian prestasi pekerjaan yang efektif, digambarkan sebagai berikut:

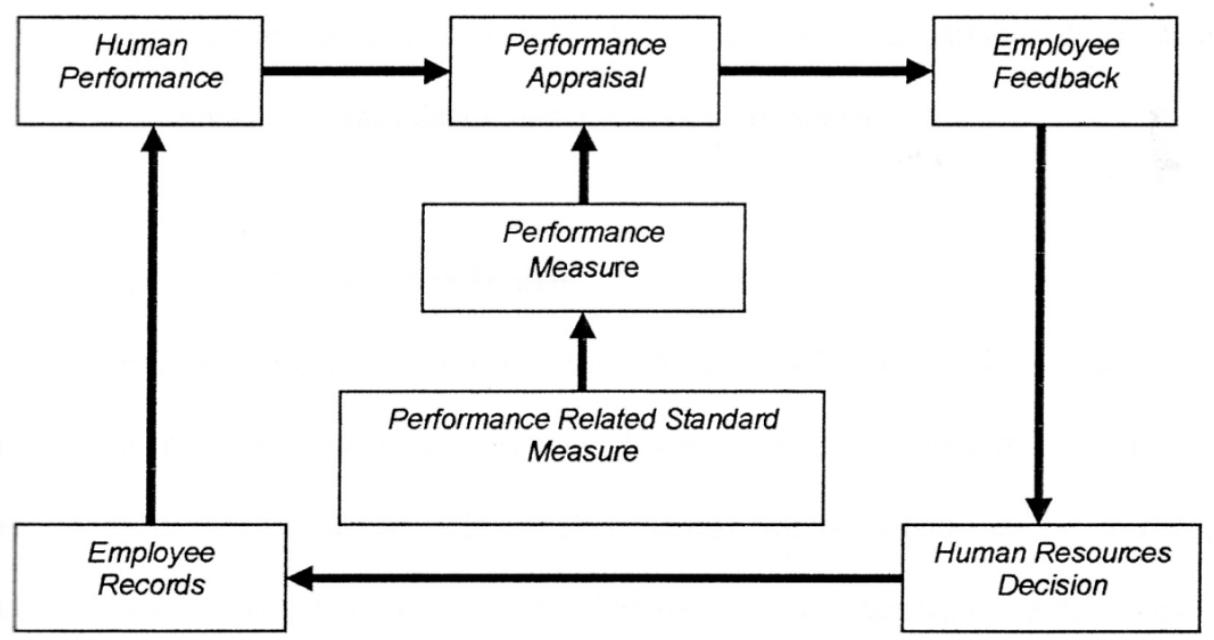

Gambar 2. Elemen-Elemen Pokok Sistem Penilaian Prestasi Pekerjaan

Sumber: Werther and Davis dalam Utomo (2006) dalam http://www.depdiknas.go.idlJurnal

Menurut gambar di atas, sistem penilaian prestasi pekerjaan terdapat beberapa sub sistem yaitu penilaian prestasi pekerjaan harus punya keterkaitan langsung dengan standar pekerjaan yang harus dicapai. Standar pekerjaan hendaknya berkaitan dengan deskripsi pekerjaan yang disyaratkan kepada pemangku jabatan. Penilaian prestasi pekerjaan hendaknya mempunyai kriteria pengukuran yang dapat diandalkan untuk setiap prestasi kerja. Jika prestasi kerja atau kriteria pengukuran tidak terkait dengan prestasi kerja karyawan, maka evaluasi tidak menjadi akurat atau bias. Sub sistem selanjutnya adalah penilaian prestasi pekerjaan harus dapat memberikan umpan 
balik baik kepada karyawan maupun kepada bagian kepegawaian organisasi bersangkutan. Umpan balik kepada karyawan yaitu berupa konseling untuk mengarahkan karyawan agar tidak melakukan kesalahan dalam bekerja. Sedangkan untuk bagian kepegawaian, berupa hasil-hasil penilaian prestasi pekerjaan selama ini employee records dapat dijadikan sebagai bahan pertimbangan dalam pengambilan keputusan mengenai sumber daya manusia, misalnya pembinaan pegawai dalam meningkatkan kinerjanya.

Penilaian kinerja bertujuan untuk menilai seberapa baik karyawan telah melaksanakan pekerjaannya dan apa yang harus mereka lakukan untuk menjadi lebih di masa mendatang. Ini dilaksanakan dengan merujuk pada isi pekerjaan yang dilakukan dan apa yang mereka harapkan untuk mencapai setiap aspek dari pekerjaan mereka. Aspek-aspek kinerja yang dipakai untuk penilaian, Rivai (2005) menyebutkan ada beberapa hal yang perlu disiap4kan antara lain isi tugas secara keseluruhan (tugas utama), yang disebut dengan istilah accountabilities atau key result areas, yang melibatkan sasaran, target kuantitas kerja dan standar kinerja suatu tugas untuk diselesaikan. Aspek-aspek tersebut dinyatakan dalam bentuk deskripsi tugas atau pembatasan peranan. Sehingga uraian tersebut dapat disimpulkan bahwa unsur yang dinilai pada seseorang karyawan pada hakekatnya adalah didasarkan atas diskripsi tugas/ job discription.

Ilyas (2002) menyebutkan obyek penilaian kinerja pada dasarnya ada 2 (dua) aspek yang dapat dinilai yaitu: keluaran dan proses atau perilaku. Kedua aspek tersebut dipergunakan tergantung pada jenis pekerjaan dan fokus penilaian yang dilakukan. Pekerjaan yang sifatnya berulang dan keluaran mudah diidentifikasi, maka penilaian biasanya difokuskan pada keluaran, sedangkan pada pekerjaan yang hasilnya sulit diidentifikasi fokus penilaian ditujukan kepada aktivitas atau proses. Penilaian kinerja adalah proses penulusuran kegiatan pribadi personel pada masa tertentu dan menilai hasil karya yang ditampilkan terhadap pencapaian sasaran sistem manajemen.

Menurut Rivai (2005) adalah 4 (empat) hal yang perlu diperhatikan saat menilai kinerja sese- orang, yaitu:1). Input, 2). Proses, 3). Output, 4). Dampak. Dalam praktiknya, pendekatan baru untuk penilian kinerja yang didasarkan atas dua aspek berikut ini: 1) Apa yang individu bawa pada pekerjaan dalam kaitannya dengan atribut dan perilaku (dikenal sebagai input), 2) Hasil apa yang akan dicapai dalam kaitannya dengan hasil dan output (dikenal sebagai output).

Agar penerapan sistem manajemen kinerja karyawan dapat secara efektif meningkatkan kinerja perusahaan dan kepuasan karyawan, tahapan penerapan sistem manajemen kinerja harus konsisten dan dimulai dari pendefinisian strategi dan target perusahaan, unit kerja sampai kelompok kerja. Sedangkan pengelolaan kinerja karyawan sendiri menurut Rivai (2005) dibagi menjadi 3 tahap, yaitu:Step 1: Perencanaan target kinerja, Step 2: Pengarahan dan pendokumentasian kinerja karyawan, Step 3: Penilaian kinerja akhir dan dokumentasi.

Menurut Blanchard (1982) konsep kematangan/maturity terdiri dari dua dimensi maturitas pekerjaan yang berkaitan dengan kemampuan/ ability untuk melakukan sesuatu dan maturitas psikologis yang dikaitkan dengan kemauan/willingness untuk melakukan sesuatu atau memikul tanggung jawab dalam mengarahkan perilaku mereka sendiri.Kematangan/maturity sebagaimana dikaji dalam penelitian ini, bukan merupakan maturitas yang berkaitan dengan tahun kronologis atau usia seseorang. Namun sebagai penilaian kemampuan dan kemauan seseorang karyawan dalam menyelesaikan masalah. (Monica, 1998) yang didasarkan atas The situationalleadership theory Hersey-Blanchard.

Hersey Blanchard menjabarkan konsep kemampuan dengan berorientasi pada Situational Leadership Theory (SLT) yang mereka temukan. Menurut teori ini tidak ada satu cara terbaik untuk mempengaruhi perilaku orang-orang. Gaya pemimpinan mana yang harus diterapkan seseorang terhadap orang-orang atau kelompok orang bergantung pada level maturitas dan orang-orang yang akan dipengaruhi pemimpin. SLT berfokus pada dua type primer dan perilaku pemimpin task dan relationship behavior (Blanchard, 1982). Hersey 
dan Blanchard mengilustrasikan sebagaimana yang tertera di gambar 3 bawah ini.

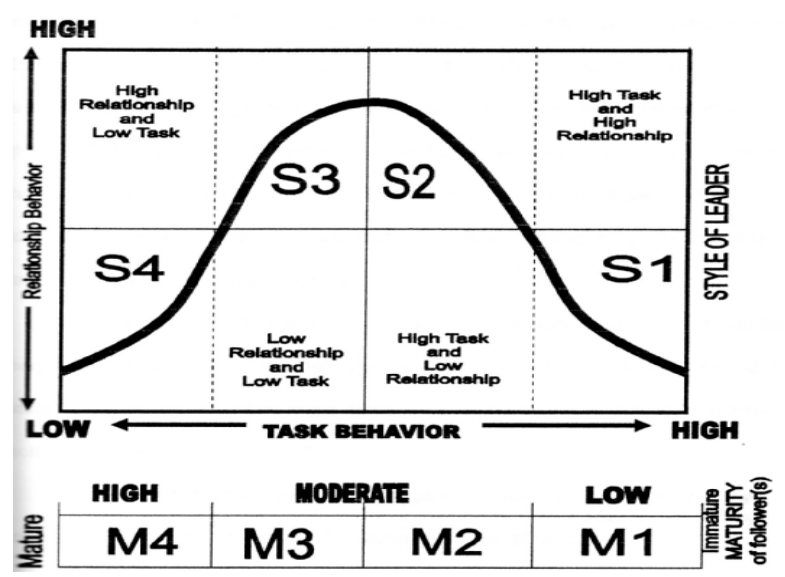

Gambar 3. Hubungan gaya kepemimpinan dan tingkat kemampuan bawahan. Diambil dari $A$ Test of the Situational Leadership Theory (Warren Blank et al, 1990)

Gambar 3. menunjukkan hubungan antara kemampuan yang berkaitan dengan perilaku hubungan dan perilaku tugas bawahan dengan gaya kepemimpinan yang sesuai untuk diterapkan. Langkah awal seorang pemimpin akan mempengaruhi bawahannya maka terlebih dahulu mendiagnosis tingkat kemampuan bawahannya.

Untuk mengkaji komponen maturitas Blanchard (1982) mengemukakan tiga pendapat. Yaitu:Pertama, menurut hasil penelitian David C. McClelland orang-orang yang bermotivasi prestasi memiliki karakteristik tertentu yang sama, termasuk kemampuan untuk menyusun tujuan yang tinggi tetapi masih terjangkau, lebih menekankan prestasi pribadi daripada imbalan keberhasilan, dan keinginan untuk memperoleh balikan atas tugas yang dilakukan, dari pada balikan sikap. Dari semua karakteristik itu, yang kaitannya dengan level maturitas untuk melaksanakan tugas tertentu, adalah kemampuan menyusun tujuan tinggi yang masih terjangkau.Kedua, dalam hubungannya dengan pendidikan dan atau pengalaman, berpendapat bahwa tidak ada perbedaan konseptual diantara keduanya. Orang dapat memperoleh kemampuan dalam tugas tertentu melalui pendidikan atau pengalaman atau kombinasi keduanya. Ketiga, pendidikan dan atau pengalaman mempengaruhi kemampuan dan motivasi berprestasi mempengaruhi kemauan. Oleh karena itu, Hersey menyatakan bahwa konsep kematangan terdiri dari dua dimensi job maturity (ability) dan psychology maturity (willingness).

Job maturity dikaitkan dengan kemampuan/ ability untuk melakukan sesuatu. Hal ini berkaitan dengan pengetahuan dan ketrampilan. Orang yang memiliki kematangan pekerjaan yang tinggi dalam bidang tertentu memiliki pengetahuan, kemampuan, dan pengalaman untuk melaksanakan tugas-tugas tertentu tanpa arahan dari orang lain. Hambleton, Blanchard dan Hersey (Jones, 1986) menyampaikan ada 12 dimensi maturitas kerja/ job maturitydimensions diantaranya past performance (hasil kerja masa lalu yang telah dilakukan), technical knowledge (pengetahuan teknikal), understanding of jobrequirements (pemahaman terhadap syaratsyarat menjalankan tugas), problem-solving ability kemampuan memecahkan masalah), ability to take responsibility (kemampuan memikul tanggung jawab), meeting job deadlines penyelesaian tugas tepat pada waktunya), past job experience (pengalaman menjalankan tugas), planning skills (kemampuan membuat perencanaan), decision making skills keterampilan mengambil keputusan), follow through (keberlangsungan pekerjaan), judgment (pertimbangan), dan problem ident (identifikasi masalah).

Psychology maturity dikaitkan dengan willingness (kemauan) untuk melakukan sesuatu. Orang yang sangat matang secara psikologis dalam bidang atau tanggungjawab tertentu merasa bahwa tanggung jawab merupakan hal yang penting serta memiliki rasa yakin terhadap diri sendiri dan merasa dirinya mampu dalam aspek pekerjaan tertentu. Mereka tidak membutuhkan dorongan ekstensif untuk mau melakukan hal-hal dalam bidang tersebut. Hambleton, Blanchard dan Hersey (Jones, 1986) menyampaikan ada 3 dimensi maturitas psikologis/ Psychology Maturity Dimensions diantaranya supportivenes (dukungan), initiative (inisiatif) dan independence (kemandirian). 
Monica (1998) menjelaskan ada 4 teori selain pendekatan SLT Hersey-Blanchard di atas yang dapat digunakan untuk mengidentifikasi kemampuan seseorang. Keempat teori tersebut adalah Teori Herarki Kebutuhan Maslow, Teori X dan teori Y McGregor, Teori Kisaran kematangan-ketidakmatangan Argyris dan Teori Hygiene - Motivator Herzberg.

Secara umum faktor yang mempengaruhi kemampuan seseorang menyelesaikan tugas perkembangannya dalam proses maturasi dapat dibagi menjadi dua faktor, yaitu faktor penunjang dan faktor penghambat. (Mappiare, 1983). Beberapa faktor yang sangat penting dalam menunjang pencapaian kemampuan seseorang sebagaimana disebutkan diantaranya dipengaruhi oleh faktor efisiensi fisik, kemampuan motorik dan kemampuan mental. Sedangkan faktor penghambat dalam usaha mencapai tingkat kemampuan adalah sebagai berikut:(1).Discontinuities in training (latihan yang tidak berkesimambungan), (2). Overprotectiveness (perlindungan yang berlebihan), (3). Prolongation of peer-group influences (perpanjangan pengaruh-pengaruh peergroup), (4). Unrealistic aspirations (aspirasi yang tidak realistik).

Harlock (1980) dalam bukunya tentang psikologi perkembangan menyebutkan bahwa tugas perkembangan sebagai kewajiban dan tanggung jawab kematangan, yang ditunjukkan dengan polapola tingkah laku wajar atau yang diharapkan seperti yang berlaku pada kebudayaan sekitarnya. Tugas perkembangan seseorang dalam memulai pekerjaannya dialami pada saat seseorang pada masa dewasa. Penguasaan tugas perkembangan seseorang akan sangat berpengaruh terhadap tugas-tugas perkembangan kemasa selanjutnya. Sejauh mana keberhasilan seseorang menyesuaikan diri terhadap pekerjaan yang dipilihnya dapat dinilai dari prestasi dalam bekerja. Kemampuan menyesuaikan tugas perkembangan ini mengambarkan tingkat maturitas seseorang dan dapat dikuti oleh prestasi kerjanya.

Kebutuhan-kebutuhan yang lebih tinggi dalam materi pekerjaan (faktor motivator) cenderung efektif memotivasi orang berprestasi tinggi atau meningkatkan tampilan kerja dan hasil kerja total seseorang (Blanchard, 1982). Faktor motivator ini sebagaimana dijelaskan dalam Monica (1998) mengambarkan tingkat kematangan lebih tinggi. Herzberg menemukan bahwa karyawan yang tidak puas dengan faktor-faktor kebersihan (maturitas lebih rendah) mempunyai penampilan kerja rendah.

Gaya diartikan sebagai suatu cara penampilan karakteristik atau tersendiri. Gaya didefinisikan sebagai hak istimewa yang tersendiri dari si ahli dengan hasil akhir yang dicapai tanpa menimbulkan isu sampingan (Nursalam, 2002). Jadi, gaya secara tidak langsung menyatakan keluwesan dan kehematan usaha yang sebaiknya dicoba oleh setiap manajer professional. Gaya kepemimpinan merupakan norma perilaku yang digunakan oleh seseorang pada saat orang tersebut mencoba mempengaruhi perilaku orang lain seperti yang ia lihat. Dalam hal ini usaha menselaraskan persepsi diantara orang yang akan mempenganuhi perilaku dengan orang yang perilakunya akan dipengaruhi menjadi amat penting kedudukannya.

Menurut para ahli terdapat beberapa gaya kepemimpinan yang dapat diterapkan dalam suatu organisasi (Nursalam, 2002), antara lain berdasarkan kekuasaan dan wewenang dan gaya menurut teori situasional Hersey Blanchard. Gaya kepemimpinan berdasarkan wewenang dan kekuasaan dibedakan menjadi empat yaitu:1). Otoriter, 2). Demokratis, 3). Partisipatif, 4). Bebas tindak (Laissez Faire).

Selanjutnya SLT Hersey-Blanchard menyarankan gaya kepemimpinan yang tepat sesuai dengan tingkat kemampuan bawahan,. Macam gaya pemimpinan tersebut dibagi menjadi 4 (empat) macam gaya antara lain sebagai benkut:1). Gaya Direktif(Tinggi Tugas Rendah Hubungan), 2). Gaya Konsultatif (Tinggi Tugas Tinggi Hubungan), 3). Gaya Participating (Rendah Tugas Tinggi Hubungan), 4). Gaya Delegating (Rendah Tugas Rendah Hubungan).

Loyalitas dari kata loyal yang berarti setia, loyal merupakan hubungan yang membuat seseorang percaya kepada orang lain.Secara umum loyalitas dapat diartikan dengan kesetiaan, pengabdian dan kepercayaan yang diberikan atau ditu- 
jukan kepada seseorang atau lembaga, yang didalamnya terdapat rasa cinta dan tanggung jawab untuk berusaha memberikan pelayanan dan perilaku yang terbaik. Hal ini selaras dengan pernyataan yang dikemukakan oleh Tim Penyusun Kamus Besar Bahasa Indonesia menyatakan bahwa loyalitas adalah kesetiaan, kepatuhan dan ketaatan. Loyalitas adalah kemauan bekerja sama yang berarti kesediaan mengorbankan diri, kesediaan melakukan pengawasan diri dan kemauan untuk menonjolkan kepentingan diri sendiri. Kesediaan untuk mengorbankan diri ini melibatkan adanya kesadaran untuk mengabdikan diri kepada perusahaan. Pengabdian ini akan selalu menyokong peran serta karyawan dalam perusahaan.

Loyalitas kerja dipengaruhi oleh tiga faktor antara lain: 1). Pribadi; pengalaman kerja seseorang atau individu yang paling untuk menunjang prestasi di sebuah perusahaan, Personal Importance, yaitu pengalaman dipandang sebagai anggota yang berharga dan produktif bagi perusahaan, 2). Realisasi dari harapan; seorang individu harus memiliki sebuah harapan yang kuat, dari pembagian-pembagian pekerjaan di perusahaan tersebut, Realizing of Expectations, yaitu dengan terpenuhi harapan-harapan individu akan meningkatkan loyalitas individu terhadap perusahaan, 3). Tantangan pekerjaan; pekerjaan yang menantang dan menarik yang disesuaikan degan kemampuan dan karakteristik dari masing-masing individu, Job Challenge, yaitu pekerjaan yang menentang dan menarik akan dapat memperkuat loyalitas kerja.

Faktor-faktor yang mempengaruhi loyalitas karyawan adalah adanya fasilitas-fasilitas kerja, tinjauan kesejahteraan, suasana kerja serta upah yang diterima dari perusahaan. Timbulnya loyalitas kerja dipengaruhi oleh antara lain:1). karaktersitik pribadi, 2). Karakteristik pekerjaan, 3). Karakteristik desain perusahaan, 4). Pengalaman yang diperoleh dari perusahaan.

Berdasarkan faktor-faktor yang telah diungkap diatas dapat dilihat bahwa masing-masing faktor mempunyai dampak tersendiri bagi kelangsungan hidup perusahaan, sehingga tuntutan loyalitas yang diharapkan oleh perusahaan baru dapat terpenuhi apabila karyaawn memiliki karakteristik seperti yang diharapkan dan perusahaan sendiri telah mampu memenuhi harapan-harapan karyawan, sehingga dapat disimpulkan bahwa faktor yang mempengaruhi loyalitas tersebut meliputi: adanya fasilitas-fasilitas kerja,tunjangan kesejahteraan, suasana kerja upah yang diterima, karakteristik pribadi individu atau karyawan, karakteristik pekerjaan, karakteristik desain perusahaan dan pengalaman yang diperolah selama karyawan menekuni pekerjaan itu.

Aspek-aspek loyalitas yang berhubungan dengan sikap yang akan dilakukan karyawan, dan merupakan proses psikologis terciptanya loyalitas kerja dalam perusahaan, antara lain: (1). Dorongan yang kuat untuk tetap menjadi anggota perusahaan, kekuatan aspek ini sangat dipengaruhi oleh keadaan individu, baik kebutuhan, tujuan maupun kecocokan individu dalam perusahaan.(2). Keinginan untuk berusaha semaksimal mungkin bagi perusahaan. Kesamaan persepsi antara karyawan dan perusahaan dan yang didukung oleh kesamaan tujuan dalam perusahaan mewujudkan keinginan yang kuat untuk berusaha maksimal, karena dengan pribadi juga perusahaan akan terwujud.(3). Kepercayaan yang pasti dan penerimaan yang penuh atas nilai-nilai perusahaan. Kepastian kepercayaan yang diberikan karyawan tercipta dari operasional dari perusahaan yang tidak lepas dari kepercayaan perusahaan terhadap karyawan itu sendiri untuk melaksanakan pekrjaannya.

Aspek-aspek loyalitas kerja yang lain terdapat pada individu yang menitik beratkan pada pelaksanaan kerja yang dilakukan karyawan suatu perusahaan antara lain yaitu: (1). Taat pada peraturankaryawan mempunyai tekat dan kesanggupan untuk menaati segala peraturan, perintah dari perusahaan dan tidak melanggar larangan yang telah ditentukan baik secara tertulis maupun tidak tertulis, (2). Tanggung jawab karakteristik pekerjaan dan prioritas tugasnya mempunyai konsekuensi yang dibebankan karyawan, (3). Sikap kerja; Sikap mempunyai sisi mental yang mempengaruhi individu dalam memberikan reaksi terhadap stimulus mengenai dirinya diperoleh dari pengalaman dapat merespon stimulus tidaklah sama. 
Perhatian terhadap karir individual dalam perencanaan karir yang telah ditetapkan, penilaian prestasi kerja baik tertib dan benar serta pemberian upah akan dapat meningkatkan loyalitas karya pada perusahaan dimana mereka bekerja. Agar karyawan mempunyai loyalitas kerja yang tinggi pada perusahaan dengan jalan mengambil perhatian,memuji kemajuan, pemindahan, kenaikan upah, promosi jabatan, memberitahukan kepada karyawan tentang apa yang terjadi pada perusahaan, membiarkannya mengerti bagaimana bekerja dengan baik serta mau mendengarkan keluhan para karyawan.

Loyalitas dibagi kedalam dua dimensi, yaitu: loyalitas sebagai perilaku/ behavior dan loyalitas sebagai sikap/attitude. Kombinasi keduanya menghasilkan empat keadaan kemungkinan loyalitas, yaitu:1) Loyalitas rendah (sikap rendah, perilaku rendah), 2) Loyalitas laten (sikap tinggi, perilaku tinggi), 3) Loyalitas superioer (sikap rendah, perilaku tinggi), 4). Loyalitas sesungguhnya (sikap tinggi, perilaku tinggi). Lebih lanjut dimensi sikap dan perilaku memiliki lima indikator, yaitu:1). Trust (kepercayaan), 2). Psycological/emotional commitment (komitmen psikologi/ emosi), 3). Switching cost (beban/biaya yang harus ditangung bila pindah organisasi), 4). Word of mouth (perilaku mempublikasikan organisasi), 5). Cooperation (perilaku kerjasama).

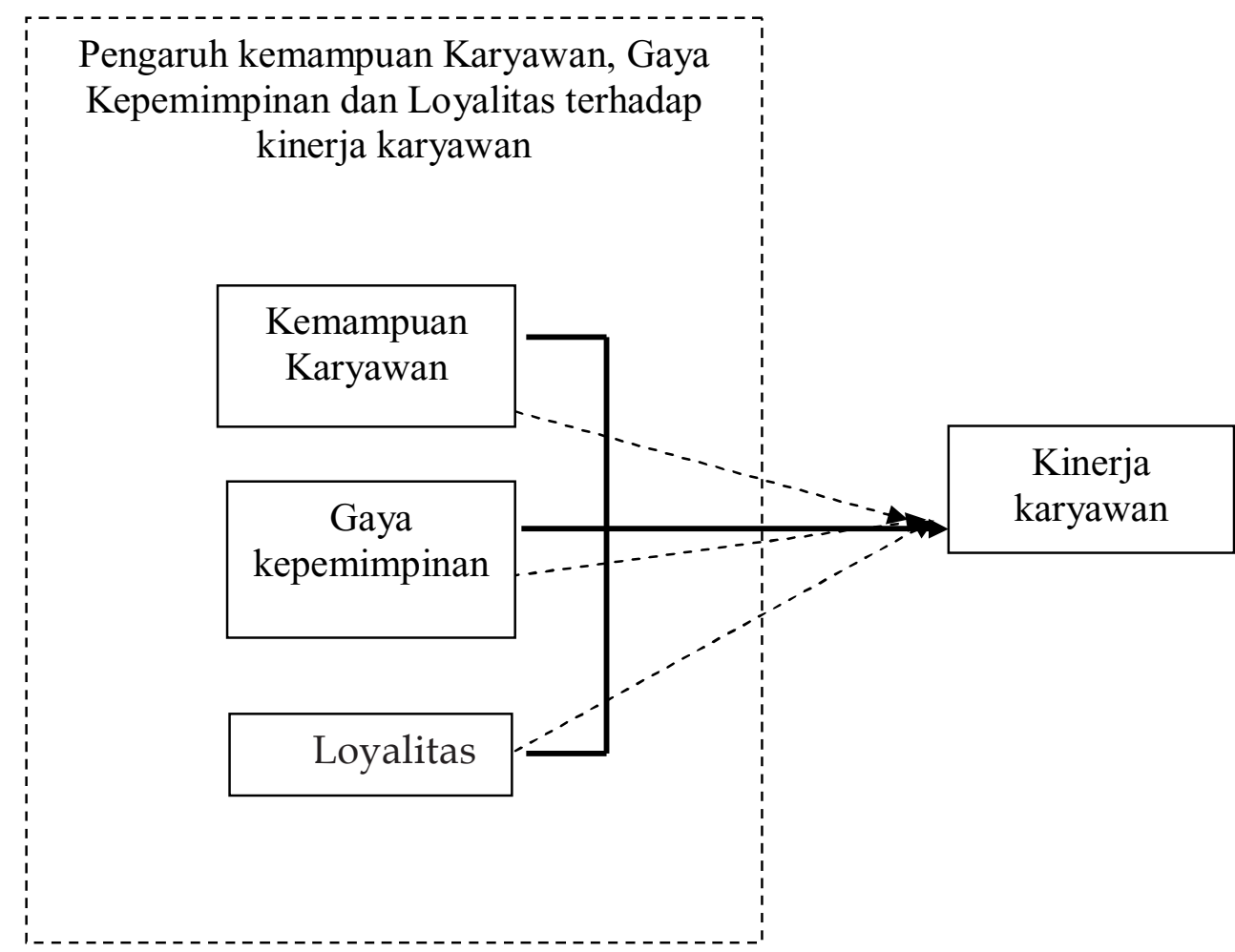

Keterangan:

Pengaruh secara simultan

Pengaruh secara parsial

Gambar 4. Kerangka Konseptual Penelitian

Berdasarkan kajian teoritis dan tinjauan pustaka yang telah diuraikan sebelumnya, secara ringkas dapat dilihat hubungan dari berbagai konsep sebagaimana tertera pada gambar 4 di atas. Dari gambar tersebut dapat dijelaskan hubungan dan pengaruh yang saling berkaitan antara konsep satu dengan yang lainnya diantaranya adalah bahwa kinerja karyawan dipengaruhi oleh faktor kemam- 
puan, loyalitas karyawan serta faktor kepemimpinan. Sedangkan aspek kemampuan meliputi hasil kerja yang telah dilakukan, pengetahuan teknikal, pemahaman terhadap syarat-syarat menjalankan tugas, kemampuan memecahkan masalah, kemampuan memikul tanggung jawab, penyelesaian tugas tepat pada waktunya, pengalaman menjalankan tugas, ketrampilan dalam perencanaan, ketrampilan mengambil keputusan, keberlangsungan pekerjaan, pertimbangan, dan kemampuan mengidentifikasi masalah. Loyalitas memilki 5 indikator, yaitu 1). Trust (kepercayaan), 2). Psycologicall emotional commitment (komitmen psikologi/ emosi), 3). Switching cost (bebab/ biaya yang harus ditanggung bila pindah organsasi), 4). Word of mouth. perilaku mempublikasikan organisasi, 5). Coorperation/ perilaku kerja sama. Selanjutnya yang mempengaruhi kinerja karyawan lainnya adalah gaya kepemimpinan, dimana aspek kepemimpinan tersebut berorientasi tugas dan hubungan. Adapun gaya kepemimpinan tersebut antara lain direktif, konsultatif, partisipatif dan delegatif.

\section{METODE PENELITIAN}

Jenis penelitian yang digunakan dalam penelitian mi adalah metode survey dengan teknik korelasional, di mana akan diperoleh fakta dan gejala untuk mengidentifikasi dan menganalisis pengaruh kemampuan karyawan $\left(\mathrm{X}_{1}\right)$, gaya kepemimpinan $\left(\mathrm{X}_{2}\right)$ dan loyalitas karyawan $\left(\mathrm{X}_{3}\right)$ terhadap kinerja karyawan (Y). Metode penelitian survey yaitu sebuah riset dimana seorang pewawancara berinteraksi dengan para responden untuk mendapatkan fakta, pendapat dan sikap. (Daniel dan Gatea, 2001). Lokasi penelitian ini adalah Rumah Sakit Jiwa Daerah Menur Surabaya Jl. Raya Menur No 120 Surabaya.

Penelitian tentang pengaruh kemampuan karyawan, gaya kepemimpinan dan loyalitas terhadap kinerja karyawan dilakukan pada bulan Maret s/d April 2011, yang mengambil obyek penelitian karyawan di Rumah Sakit Jiwa Daerah Menur Surabaya. Sedangkan subyek penelitian adalah karyawan di Rumah Sakit Jiwa Daerah Menur
Surabaya tanpa membedakan status, pangkat, golongan, ruang, masa kerja dan usia.

Populasi penelitian adalah karyawan Rumah Sakit Jiwa Daerah Menur Surabaya yang berjumlah 376 orang, terdiri dari tenaga kesehatan sebanyak 144 orang, dan tenaga non kesehatan sebanyak 232 orang. Besarnya Sampel dalam penelitian ini ditentukan berdasarkan Tabel Krecjie dengan tingkat kesalahan $5 \%$ dan Nomogram Harry King (Sugiono, 2006) dengan jumlah populasi 376 orang. Jumlah sampel untuk tenaga kesehatan minimal $=42$ orang sedangkan tenaga non kesehatan $=89$ orang, total jumlah yang harus diambil= 131 orang. Sedangkan teknik sampling dalam penelitian ini dengan proportionate stratified random sampling dengan cara undian. Tehnik pengambilan sampel yang didasarkan atas proporsi besarnya populasi tenaga kesehatan dan tenaga non kesehatan.

Variabel-variabel yang akan dianalisis dalam penelitian ini terdiri dari dua variabel yaitu variable bebas (independent variable) dan variable terikat (dependent variable). Variabel bebas (independent varisble) dalam penelitian ini adalah: (1) Kemampuan karyawan $\left(\mathrm{X}_{1}\right)$, (2) Gaya kepemimpinan $\left(\mathrm{X}_{2}\right)$ Atasan atau pimpinan yang terdiri dari 2 sub variabel orientasi tugas dan orientasi hubungan.(3) Loyalitas karyawan $\left(\mathrm{X}_{3}\right)$. Sedangkan variabel terikatnya (dependent variable) adalah kinerja karyawan (Y).

Sumber data yang digunakan dalam penelitian ini adalah data primer dan data sekunder. Data primer yaitu data yang diperoleh langsung/ hasil survei pendapat responden dalam hal ini Karyawan Rumah Sakit Jiwa Daerah Menur Surabaya tentang kemampuan karyawan, gaya kepemimpinan, loyalitas dan kinerja karyawan dengan menggunakan instrumen penelitian. Instrumen penelitian yang dipergunakan dalam penelitian ini adalah kuisioner. Instrumen yang digunakan untuk mengukur tingkat kemampuan terdiri dari 12 pertanyaan yaitu untuk mengukur Job Maturity. Instrumen untuk mengukur gaya kepemimpinan terdiri dari 18 pertanyaan. Instrumen loyalitas karyawan dari 10 pertanyaan. Sedangkan untuk mengukur kinerja 
karyawan terdiri dari 14 pertanyaan. Semua instrumen ambil dari hasil kumpulan instrumen menurut Mas'ud (2004). Data sekunder yaitu data yang diperoleh dari studi pustaka, data internal yang menyangkut gambaran umum kondisi Rumah Sakit Jiwa Daerah Menur Surabaya.

Metode yang digunakan adalah metode survey terstruktur. Data dikumpulkan dengan menanyai karyawan melalui daftar pertanyaan atau kuesioner. Kuesioner akan diberikan pada semua karyawan Rumah Sakit Jiwa Daerah Menur Surabaya, yang dibuat bersifat tertutup dengan pertimbangan memudahkan responden dalam menjawab pertanyaan-pertanyaan yang diajukan, selain pertimbangan waktu yang terbatas. Pengumpulan data ini bermanfaat untuk mendapatkan skor item pertanyaan yang akan diolah sesuai dengan model analisisnya.

Metode analisa data yang digunakan dalam penelitian adalah regresi korelasi, yaitu:analisis statistik inferensial. Statistik inferensial, yaitu statistik yang digunakan untuk menganalisis pengaruh variabel bebas, baik secara simultan maupun parsial. Model analisis yang digunakan adalah regresi linier berganda. Model persamaan dalam penelitian ini adalah: $Y=\alpha+\beta_{1} X_{1}+\beta_{2}+X_{2}+\beta_{3} X_{3}+e$

\section{Dimana:}

$\mathrm{Y}=$ Kinerja karyawan

$\alpha=$ Konstanta

$\beta=$ Bilangan koefisien

$\mathrm{X}_{1}=$ Ilkim organisasi

$\mathrm{X}_{2}=$ Motivasi kerja

$\mathrm{X}_{3}=$ Kepuasan kerja

$\mathrm{e}=$ Disturbance error

Penelitian ini menggunakan metode statistik yang akan dipergunakan dalam mengelolah datadata yang telah terkumpul, sehingga data- data yang telah terkumpul dapat diolah dan menghasilkan suatu kesimpulan mengenai permasalahan yang dibahas dalam penelitian ini. Instrumen pengumpulan data yang baik harus memenuhi 3 persyaratan penting yaitu valid, reliable dan berdistribusi normal, untuk itu dilakukan uji validitas, realibilitas dan normalitas.

\section{HASIL PENELITIAN DAN PEMBAHASAN}

Dengan menggunakan bantuan SPSS for Windowsver 13.00 didapat model regresi seperti pada Tabel 1:

Tabel 1. Persamaan Regresi

\begin{tabular}{cccccc}
\hline \multirow{2}{*}{ Model } & \multicolumn{2}{c}{ Unstandardized Coefficients } & $\begin{array}{c}\text { Standardized } \\
\text { Coefficients }\end{array}$ & t & Sig. \\
\cline { 2 - 4 } & B & Std. Error & Beta & & \\
\hline 1 (Constant) & 15,056 & 5,068 & - & 2,971 & 0,004 \\
X1 & 0,033 & 0,067 & 0,035 & 0,496 & 0,621 \\
X2 & 0,206 & 0,082 & 0,226 & 2,505 & 0,014 \\
X3 & 0,597 & 0,100 & 0,555 & 5,953 & 0,000 \\
\hline
\end{tabular}

Berdasarkan Tabel 1 didapatkan persamaan regresi sebagai berikut:

$Y=15,056+0.033 X_{1}+0.206 X_{2}+0.597 X_{3}$

Berdasarkan interpretasi di atas, dapat diketahui besarnya kontribusi variabel bebas terhadap variabel terikat, antara lain Kemampuan karyawan sebesar 0.033, Gaya kepemimpinan sebesar 0.207, Loyalitas sebesar 0.597. Sehingga dapat disimpulkan bahwa Kemampuan karyaw an $\left(\mathrm{X}_{1}\right)$, Gaya kepemimpinan $\left(\mathrm{X}_{2}\right)$, Loyalitas $\left(\mathrm{X}_{3}\right)$ berpengaruh positif terhadap Kinerja. Dengan kata lain, apabila Kemampuan karyawan $\left(\mathrm{X}_{1}\right)$, Gaya kepemimpinan $\left(\mathrm{X}_{2}\right)$, Loyalitas $\left(\mathrm{X}_{3}\right)$ meningkat maka akan diikuti peningkatan Kinerja. Hasil analisis regresi di atas menunjukkan bahwa faktor yang memberi pengaruh positif terhadap Kinerja adalah semua variabel bebas. Hasil koefisien determinasi $\left(\mathrm{R}^{2}\right)$, nilai $\mathrm{R}^{2}$ seperti dalam Tabel 4.10 berikut ini: 
Tabel 2. Koefisien Korelasi dan Determinasi

\begin{tabular}{cccccc}
\hline Model & R & R Square & Adjusted R Square & $\begin{array}{c}\text { Std. Error of the } \\
\text { Estimate }\end{array}$ & Durbin- Watson \\
\hline 1 & 0,763 & 0,582 & 0,572 & 4,92041 & 1,855 \\
\hline
\end{tabular}

Sumber: Data primer diolah

Dari analisis pada Tabel 4.10 diperoleh hasil $\mathrm{R}^{2}$ (koefisien determinasi) sebesar 0,582. Artinya bahwa 58,2\% variabel kinerja akan dipengaruhi oleh variabel bebasnya, yaitu Kemampuan karyawan $\left(\mathrm{X}_{1}\right)$, Gaya kepemimpinan $\left(\mathrm{X}_{2}\right)$, Loyalitas $\left(\mathrm{X}_{3}\right)$. Sedangkan sisanya $41,8 \%$ variabel kinerja akan dipengaruhi oleh variabel-variabel yang lain yang tidak dibahas dalam penelitian ini.

Selain koefisien determinasi juga didapat koefisien korelasi yang menunjukkan besarnyahubungan antara variabel bebas yaitu Kemampuan karyawan, Gaya kepemimpinan, Loyalitas dengan variabel Kinerja, nilai R (koefisien korelasi) sebesar 0.763 , nilai korelasi ini menunjukkan bahwa hubungan antara variabel bebas yaitu Maturisasi karyawan $\left(\mathrm{X}_{1}\right)$, Gaya kepemimpinan $\left(\mathrm{X}_{2}\right)$, Loyalitas $\left(\mathrm{X}_{3}\right)$, dengan Kinerja termasuk kategori kuat karena berada pada selang 0,6-0,8. Hubungan antara variabel bebas yaitu Kemampuan karyawan $\left(\mathrm{X}_{1}\right)$, Gaya kepemimpinan $\left(\mathrm{X}_{2}\right)$, Loyalitas $\left(\mathrm{X}_{3}\right)$ dengan Kinerja bersifat positif, artinya jika variabel bebas semakin ditingkatkan maka kinerja juga akan mengalami peningkatan.

Dari hasil keseluruhan dapat disimpulkan bahwa variabel bebas (Kemampuan karyawan $\left(\mathrm{X}_{1}\right)$, Gaya kepemimpinan $\left(\mathrm{X}_{2}\right)$, Loyalitas $\left(\mathrm{X}_{3}\right)$ ) mempunyai pengaruh yang signifikan terhadap Kinerja secara simultan dan parsial. Dan dari sini dapat diketahui bahwa ketiga variabel bebas tersebut yang paling dominan pengaruhnya terhadap Kinerja adalah loyalitas karena memiliki nilai koefisien beta dan thitung paling besar.

Berdasarkan hasil analisis regresi linier berganda, ternyata kemampuan karyawan, gaya kepemimpinan dan loyalitas berpengaruh positif terhadap kinerja karyawan Rumah Sakit Jiwa Daerah Menur Surabaya. Hal ini dapat diartikan bahwa kemampuan karyawan, gaya kepemimpinan serta loyalitas berpengaruh signifikan terhadap kinerja.
Dapat disimpulkan bahwa secara simultan kemampuan karyawan, gaya kepemimpinan dan loyalitas semakin ditingkatkan maka kinerja karyawan juga mengalami peningkatan secara nyata. Adapun besarnya pengaruh atau kontribusi variabel bebas yaitu kemampuan karyawan, gaya kepemimpinan dan loyalitas terhadap variabel terikat yaitu Kemampuan karyawan sebesar 58,2\%. Sedangkan sisanya 41,8\% variabel kinerja dipengaruhi oleh varabel-variabel lain yang tidak dibahas dalam penelitian ini. Secara parsial pengaruh kemampuan karyawan terhadap kinerja tidak signifikan sehingga dapat disimpulkan bahwa dengan meningkatkan kemampuan karyawan maka kinerja tidak mengalami peningkatan secara nyata. Pengaruh gaya kepemimpinan terhadap kinerja signifikan sehingga dapat disimpulkan bahwa dengan meningkatkan gaya kepemimpinan maka kinerja mengalami peningkatan secara nyata. Pengaruh loyalitas terhadap kinerja signifikan sehingga dapat disimpulkan bahwa dengan meningkatkan loyalitas maka kinerja mengalami peningkatan secara nyata. Dari hasil keseluruhan dapat disimpulkan bahwa variabel bebas (Kemampuan karyawan $\left(\mathrm{X}_{1}\right)$, Gaya kepemimpinan $\left(\mathrm{X}_{2}\right)$, Loyalitas $\left(\mathrm{X}_{3}\right)$ ) mempunyai pengaruh yang signifikan terhadap variabel terikat (Kinerja (Y)) secara simultan dan parsial. Dan dari sini dapat diketahui bahwa ketiga variabel bebas tersebut yang paling dominan pengaruhnya terhadap kinerja adalah loyalitas karena memiliki nilai koefisien beta dan thitung paling besar.

Hal tersebut diatas sesuai dengan pendapat Kopelman (1998) menyebutkan bahwa faktor yang mempengaruhi kinerja adalah: karakteristik individu, karakteristik organisasi dan karakteristik pekerjaan, lebih lanjut beliau menjelaskan bahwa kinerja selain dipengaruhi oleh faktor di atas juga dipengaruhi oleh faktor lingkungan. Faktor karakteristik individu terdiri dari:1) Pengetahuan / knowl- 
edge, 2) Keterampilan / skills,3) Kemampuan/ abilities,4) Motivasi/ motivation,5) Norma dan nilai/ beliefs and values,6) Sikap/ attitude dan loyalitas.

Karakteristik organisasi terdiri dari: 1). Imbalan/ reward system, 2). Tujuan/ goal setting and $M B O, 3)$. Seleksi/ selection, 4). pelatihan dan pengembangan/training and development, 5). Kepemimpinan/leadership, 6). struktur organisasi/ organization structure. Sedangkan karakteristik pekerjaan diri dari: 1). tujuan umpan balik kinerja/ objectiveperformance feedback, 2). penilaian umpan balik kinerja/ judgemental performance feedback, 3). rancangan kinerja/ job design, 4). jadwal kerja/ workschedule.

Karakteristik individu bersama lingkungan akan menghasilkan produktifitas yang secara berturut-turut berupa perilaku pekerjaan atau behavior, penampilan kerja/ job performance dan efektifitas organisasi/ organizational effectivenes. Hasil akhir dari ketiga variabel tersebut menentukan kinerja yang ditampilkan dalam perilaku kerja/ work behaviors yang berlanjut menentukan penampilan kerja/ job performance dan produktivitas/ productivity.

Berdasar hasil penelitian pada karyawan Rumah Sakit Jiwa Daearah Menur bahwa pengaruh loyalitas terhadap kinerja karyawan adalah positif artinya dapat disimpulakan bahwa kinerja karyawan dapat dipengaruhi secara signifikan oleh loyalitas atau dengan meningkatnya loyalitas maka kinerja karyawan akan mengalami peningkatan secara nyata. Hal ini menunjukkan bahwa di Rumah Sakit Jiwa Daerah Menur faktor persepsi dan perilaku loyalitas mempengaruhi kinerja adalah yaitu pimpinan tidak pernah mengambil keuntungan dengan menipu karyawan, karyawan merasa puas dan bangga menjadi bagian dari organisasi, karyawan setia pada pimpinan, bersedia bekerja ekstra dan saling bekerja sama dalam melakukan yang terbaik bagi kepentingan organisasi.

Sebagaimana sikap disebutkan dalam Monica (1998) bahwa perilaku seseorang ditentukan oleh perubahan pengetahuan yang kemudian membentuk persepsi dan sikap. Azwar (1998) menjelaskan bahwa sikap adalah suatu bentuk evaluasi atau reaksi perasaan. Sikap seseorang terhadap suatu obyek adalah perasaan mendukung atau memihak/ favorable maupun perasaan tidak atau tidak memihak/ unfavorable pada obyek tersebut. Sikap juga merupakan semacam kesiapan untuk bereaksi terhadap suatu obyek dengan cara-cara tertentu.

Kepribadian karyawan menentukan kemampuannya dalam berinteraksi dan bereaksi dari lingkungan baik lingkungan fisik maupun sosial sehingga berpengaruh terhadap kinerja. Menurut May dalam Purwanto (1999) bahwa kepribadian itu yang membuat seseorang berhasil atau memberi pengaruh kepada orang lain. Robbins (2003) mendefinisikan kepribadian sebagai keseluruhan total cara seseorang individu bereaksi dan berinteraksi dengan yang lain. Kepribadian dipengaruhi oleh keturunan, budaya dan faktor sosial. Alport dalam Purwanto (1999) mengatakan bahwa pada kepribadian didapati beberapa unsur yaitu adanya gambaran suatu susunan yang dinamis, didapati gambaran sistem mengenai psikofisis individu dan sangat menentukan bagi penyesuaian diri yang unik terhadap lingkungan. Berdasarkan konsep tersebut di atas jelas bahwa kepribadian karyawan yang beragam sangat menentukan sukses atau tidaknya seseorang bekerja.

Kinerja karyawan dalam penelitian ini adalah prestasi yang dicapai oleh karyawan Rumah Sakit Jiwa Daerah Menur Surabaya dalam melaksanakan tugasnya atau kerjaannya sesuai dengan standar dan kriteria perilaku kerja yang ditetapkan. kinerja karyawan dipengaruhi oleh beberapa faktor, kemungkinan diantaranya faktor individu (kemampuan, ketrampilan, biografis, persepsi, sikap, kepribadian, pembelajaran, motivasi dan maturitas), faktor organisasi (struktur, teknologi, dan iklim kerja) dan faktor manajerial (komunikasi, kepemimpinan, pengambilan keputusan, dan pemberian motivasi (Ilyas, 2002; Robbins, 2003 dan Monica, 1998).

Berdasarkan hasil penelitian faktor yang mempengarui kinerja karyawan, pada penelitian ini adalah faktor individu yaitu kemampuan karyawaan dan loyalitas karyawan serta faktor managerial yaitu gaya kepemimpinan terhadap kinerja karyawan 
Rumah Sakit Jiwa Daerah Menur Surabaya. Hal ini dipertimbangkan bahwa di dalam upaya penyelenggaraan pelayanan kesehatan sangat ditentukan oleh SDM yang tersedia, sebagai modal dasar. Untuk menggerakkan organisasi dan mengembangkan kearah kemajuan dibutuhkan SDM yang handal yaitu yang memiliki tingkat kemampuan serta loyalitas yang tinggi. Fokus pada penggerak utama organisasi yaitu pemimpin organisasi, yaitu bagaimana pemimpin menjalankan gayanya di dalammempengaruhi bawahannya sehingga mampu menuju pada tingkat kinerja yang tinggi.

Hasil penelitian pada Karyawan Rumah Sakit Jiwa Daerah Menur terdapat perbedaan jumlah karyawan tenaga kesehatan dan non kesehatan. Jumlah tenaga kesehatan terdapat 144 karyawan yang terdiri dari 30 tenaga medis, 81 perawat dan 33 paramedis non perawat. Sedangkan tenaga non kesehata adalah 232 karyawan. Artinya terdapat lebih banyak karyawan non tenaga kesehatan yaitu 232 atau $61,7 \%$ yang memiliki tingkat kemampuan, ketrampilan, pembelajaran yang rendah tentang kesehatan. Hal ini dimungkinkan hasil penelitian pada karyawan Rumah sakit Jiwa daerah Menur Surabaya menunjukkan maturitas karyawan terhadap kinerja adalah tidak signifikan. Sehingga dapat disimpulkan dengan meningkatkan kemampuan karyawan maka kinerja tidak mengalami peningkatan secara nyata.

Hal ini merujuk teori dari Robbins (2003) dan Monica (1998) bahwa kemampuan/ ability karyawan merupakan suatu kapasitas seseorang dalam menyelesaikan pekerjaan yang ditentukan oleh kemampuan intelektual maupun kemampuan fisik. Faktor masih rendahnya kinerja karyawan ini dimungkinkan salah satunya faktor kemampuan. Kemampuan ini dapat dilihat dari variasinya latar belakang karyawan, diantaranya usia, pengalaman, dan pendidikan.

Faktor rendahnya kinerja karyawan bisa disebabkan oleh faktor ketrampilan dalam pekerjaan. Ketrampilan ini adalah suatu kompetensi yang berhubungan dengan pekerjaan. Karyawan memiliki kompetensi berarti juga mempunyai kecakapan atau keahlian dalam pekerjaannya. Semakin tinggi ketrampilan karyawan dalam bidang tugasnya maka semakin mudah menjalankan pekerjaanya. Tidak mustahil bahwa dunia kerja menuntut ketrampilan karyawan pada saat rekruitmen maupun menjalankan pekerjaan. Ketrampilan dapat diperoleh dari pendidikan dan latihan, atau program job training bagi tenaga baru sebelum diberikan pekerjaan. Sebagaimana dalam teori Situational Leadership Theory (SLT) Hersey Blanchard, menunjukkan hubungan antara kemampuan yang berkaitan dengan perilaku hubungan dan perilaku tugas bawahan dengan gaya kepemimpinan yang sesuai untuk diterapkan. Langkah awal seorang pemimpin akan mempengaruhi bawahannya maka terlebih dahulu mendiagnosis tingkat kemampuan bawahannya. Berdasar teori tersebut penelitian ini akan mengidentifikasi gaya yang sesuai bagi pemimpin sesuai dengan level kemampuan serta loyalitas karyawan.

Hasil dari penelitian pada Karyawan Rumah Sakit Jiwa Daearah Menur Surabaya terdapat variasi usia, sedangkan yang terbanyak adalah berusia antara 30- 40 tahun yaitu 38,16\% hal ini sesuai dengan teori bahwa kinerja karyawan bisa dipengaruhi oleh faktor biologis, diantaranya faktor usia karyawan. Robbins (2003) menyatakan bahwa kinerja akan merosot dengan bertambahnya usia. Pekerja tua dianggap kurang luwes dan menolak teknologi baru, namun begitu pekerja tua punya pengalaman, pertimbangan, etika kerja yang kuat dan komitmen terhadap mutu. Umur berbanding terbalik terhadap kemangkiran, dimana pekerja yang tua lebih kecil kemungkinan untuk berhenti bekerja. Umur juga berpengaruh terhadap produktivitas, dimana makin tua pekerja makin merosot produktivitasnya, karena ketrampilan, kecepatan, kecekatan, kekuatan dan koordinasi menurun dengan berjalannya waktu. Selain hal tersebut usia mempengaruhi kepuasan seseorang, semakin tua pada kelompok profesional kepuasan cenderung semakin meningkat dan sebaliknya pada kelompok non-profesional. Berdasarkan kajian usia didapatkan tentang usia dari kurang 1 tahun sampai dengan 30 tahun.

Hasil penelitian pada Karyawan Rumah Sakit Jiwa Daerah Menur Surabaya terdapat perbedaan jumlah karyawan berdasarkan jenis kelamain, 
terdapat karyawan wanita lebh banyak yaitu $57,25 \%$. Sesuai dengan teori bahwa Selain usia mempengaruhi kinerja karyawan faktor lain yang mungkinkan adalah gender. Robbins (2003) menyatakan bahwa wanita lebih mematuhi wewenang sedang pria lebih agresif dan lebih besar kemungkinannya dalam memiliki pengharapan untuk sukses.

Berdasar hasil penelitian pada karyawan Rumah Sakit Jiwa Daearah Menur bahwa pengaruh loyalitas terhadap kinerja karyawan adalah positif artinya dapat disimpulakan bahwa kinerja karyawan dapat dipengaruhi secara signifikan oleh loyalitas atau dengan meningkatnya loyalitas maka kinerja karyawan akan mengalami peningkatan secara nyata. Hal ini menunjukkan bahwa di Rumah Sakit Jiwa Daerah Menur faktor persepsi dan perilaku loyalitas mempengaruhi kinerja adalah yaitu pimpinan tidak pernah mengambil keuntungan dengan menipu karyawan, karyawan merasa puas dan bangga menjadi bagian dari organisasi, karyawan setia pada pimpinan, bersedia bekerja ekstra dan saling bekerja sama dalam melakukan yang terbaik bagi kepentingan organisasi.

\section{SIMPULAN}

Kemampuan karyawan, gaya kepemimpinan dan loyalitas mempunyai pengaruh yang signifikan terhadap kinerja karyawan Rumah Sakit Jiwa Daerah Menur Surabaya secara simultan.Gaya kepemimpinan dan loyalitas mempunyai pengaruh yang signifikan terhadap kinerja karyawan Rumah Sakit Jiwa Daerah Menur Surabaya secara parsial, sedangkan kemampuan karyawan terhadap kinerja adalah tidak signifikan. Loyalitas mempunyai pengaruh paling dominan terhadap kinerja karyawan Rumah Sakit Jiwa Daerah Menur Surabaya.

\section{DAFTAR PUSTAKA}

Azwar, 1998. Sikap MAnusia Teori dan Pengukurannya. Yogyakarta. Pustaka Pelajar.hlm $4-157$
Depkes RI, 2000. Kepmenkes RI No. HK.OO.S.J.SK.VII.0888 tentang Pemberlakuan Petunjuk Pelaksanaan dan Borang Akreditasi Institusi Pendidikan Tenaga Kesehatan. Jakarta. Depkes RI. Hal 1

Gary, Yulk, 2005. Kepemimpinan Dalam Organisasi. Jakarta. PT Indeks Kelompok Gramedia. Hlm 3 - 4

Gibson, 1996. Organisasi, Perilaku, Struktur, Proses, Jakarta: Bina Rupa Aksara, hlm 119 $-275$

Harlock, 1980. Psikologi Perkembangan Suatu Pendekatan Sepanjang rentang Kehidupan, edisi kelima, Jakarta: Penerbit Erlangga

Hermawan, Utomo, 2006. Evaluasi Terhadap Sistem Penilaian Prestasi Kerja Menurut Sistem DP.http://www.depdiknas.go.id/jurnal Hersey, Blanchard, 1982. Manajemen Perilaku Organisasi: Pendayagunaan Sumber Daya Manusia. Edisi keempat alih bahasa Agus Dharma. Jakarta. Penerbit Erlangga

Ilyas, Y, 2002. Kinerja, Teori, Penilaian dan Penelitian, Jakarta: Pusat Kajian Ekonomi Kesehatan Fakultas Kesehatan Masyarakat, hlm $65-159$

John e. Jones, 1986. Instrumentation, Group \& Organization Studies, International Authors, B.V

Kopelman, 1986. Managing Produktivity In Organizations: A Practical, People Oriented Perspective. New York.McGraw-Hill

Marppiare, 1983. Psikologi Orang Dewasa. Surabaya. Usaha Nasional

Mas'ud, Fuad. 2004. Survei Diagnosis Organisasional (Konsep dan Aplikasi). BP Universitas Diponegoro. Semarang.

Mathis, 2001. Manajemen Sumber Daya Manusia, Buku 1, Jakarta: PT. Salemba Emban Patria, EGC.hlm 75 - 114

Monica, 1998. Kepemimpinan dan Manajemen Keperawatan Pendekatan Berdasarkan Pengalaman. Alih Bahasa Dra. Elly N. SKp, M. App. Sc dkk. Jakarta. EGC.hlm 30 - 85 Nursalam, 2002. Manajemen Keperawatan Aplikasi dalam Praktek Keperawatan Profesional. Jakarta. Salemba Medika 
58 Jurnal Manajemen Bisnis • Volume 2 No. 01 • Edisi April 2012

Purwanto, H,1999. Pengantar Perilaku Manusia Untuk Keperawatan. Jakarta. EGC,hlm 111 $-125$

Purwanto, 2005. Reformasi Administrasi Negara Indonesia (Sebuah Pemikiran Konseptual Untuk Meningkatkan Kinerja Administrasi Negara). Jakarta. Journal Universitas Terbuka.

Rivai, 2005. Manajemen Sunber Daya Manusia Untuk Perusahaan: Dari Teori ke Praktek. Jakarta: PT. Raja Grafindo Persada.
Rivai, 2005. Performance Appraisal. Jakarta: PT. Raja Grafindo Persada

Robbins, S, 2003. Perilaku Organisasi, Jakarta. PT. Indeks,hlm 14 - 80

Sugiono. 2002. Statistika Untuk Penelitian. Alfabeta. Bandung

Tim Penyusun Kamus Pusat Bahasa,2001. Kamus Besar Bahasa Indonesia, Jakarta: Balai Pustaka 